7. Reprod. Fert. (1971) 26, 149--159

\title{
REPRODUCTION IN ELEPHANT-SHREWS (MACROSCELIDIDAE) WITH SPECIAL REFERENCE TO OVULATION AND IMPLANTATION
}

\author{
H. R. H. TRIPP* \\ Wellcome Institute of Comparative Physiology, The Zoological Society of London, \\ Regent's Park, London, N.W.1 \\ (Received 3rd August 1970)
}

\begin{abstract}
Summary. Preserved reproductive tracts of eleven species of elephantshrew were examined histologically and experiments were performed upon captive animals. Recently formed GL were found to be everted out of the surface of the ovary. Ovulation rates, estimated from GL counts, were found to be very high in some species but low in others. Ovulation was induced in one species by administration of a pituitary extract. With the exception of one species, the litter sizes never exceeded two and implantation appeared to be restricted to two localized sites in the uterus. A median uterus functionally replaced the vagina in elephantshrews. These findings are discussed in relation to previous studies of these and other mammals.
\end{abstract}

\section{INTRODUGTION}

The elephant-shrews, family Macroscelididae, have been classified in the order Insectivora (Simpson, 1945), but it has been suggested that they be placed in a separate order, the Macroscelidea (Butler, 1956). This view is supported by Patterson (1965), who has reviewed the phylogenetic position of the family in the light of their fossil forms. The family Macroscelididae is confined to the continent of Africa and according to Corbet \& Hanks (1968) consists of four genera and fourteen species.

The literature on the reproduction of elephant-shrews consists almost entirely of a series of thirty-five papers by Van der Horst, Gillman and their students, published between 1940 and 1954. These studies were based upon the histology of the female reproductive organs of specimens of Elephantulus myurus which had been caught in the wild. Since these papers have been reviewed fully elsewhere (Tripp, 1970) only those findings that are relevant to this paper are mentioned below.

It was reported in E. myurus that the zonae pellucidae were shed from the ova at the time of ovulation and that the corpora lutea (CL) formed by evertion out of the surface of the ovary (Van der Horst \& Gillman, 1940b). It was claimed that, in this species, an average of 120 ova were released at each ovulation and yet not more than two young were born in a litter (Van der Horst \& Gillman,

* Present address: Ridgeway, Lymington, Hants. 
1941). Many of the ova were fertilized and cleaved to form four-cell embryos, but only two embryos were able to develop further and attach at the restricted implantation sites, one at the caudal end of each uterine horn (Van der Horst \& Gillman, 1942). Of five other species that were examined, only $E$. edwardi and Macroscelides proboscideus showed evidence of polyovulation (Van der Horst, 1944). It was noted that ovulation post partum occurred frequently in E. myurus (Van der Horst, 1951). Histological study of the reproductive tract of this species revealed that a true vagina was absent. It was functionally replaced by a median extension of the uterus (Van der Horst, 1942).

The intention of the present study was to check these reported observations and extend them to a greater number of species. Experiments were performed in the hope of finding a physiological explanation for the variations in the mean ovulation rates reported for different species of elephant-shrew.

\section{MATERIALS AND METHODS}

Sources of animals and materials

Live specimens of $E$. myurus were caught near Johannesburg, South Africa, during the early part of the breeding season which extends from July to January. Specimens of $E$. intufi were caught in north eastern Transvaal, Petrodromus tetradactylus were caught in northern Natal and live $E$. rozeti were obtained from Morocco. All live animals were sent by air freight to England.

Preserved material of these and seven other species ( $E$. rufescens, E. brachyrhynchus, E. fuscipes, E. rupestris, E. edwardi, M. proboscideus and Rhynchocyon petersi) was obtained from various sources. In addition, the histological material of the late G. J. Van der Horst was studied in Johannesburg.

\section{Maintenance of animals and procedures}

Animals were normally housed as pairs in floor-pens ( $3 \mathrm{ft} \times 3 \mathrm{ft} \times 15$ in. high) and in cages (24 in. $\times 15$ in. $\times 10$ in. high) with wooden floors. Nest boxes and trays of sand were provided. They were fed a mixed diet of live insects (locusts and mealworms), fruit and vegetables. Room temperature was kept between $20^{\circ}$ and $23^{\circ} \mathrm{C}$. Artificial light was regulated between $10 \frac{1}{2}$ and $14 \mathrm{hr} /$ day.

Reproductive organs were dissected from dead specimens and were fixed either in Bouin's fluid or in 5\% formol-saline and selected tissues were processed routinely for histological examination. Serial sections were cut at $5 \mu \mathrm{m}$ and stained with Harris's haematoxylin and eosin. The follicles and the GL were measured in two dimensions with an eyepiece micrometer and were counted from serial sections, scanned with the low power $(\times 30)$ of a microscope.

A micrometer syringe was used to deliver $10 \mu \mathrm{l}$ of a solution of $17 \beta$-oestradiol in distilled water into the genital opening of five $E$. myurus and three laboratory mice. Saline lavage smears were taken from eight $E$. myurus for 2 months and one for 5 months and stained with Harris's haematoxylin and eosin. For the experimental induction of ovulation, solutions of PMSG (Gestyl, Organon) and HCG (Pregnyl, Organon) were made up in sterile, distilled water and injected subcutaneously. An extract of gelding pituitary glands (AP70B) dissolved in sterile, distilled water of $\mathrm{pH} 7 \cdot 2$ to $7 \cdot 4$ was also injected subcutaneously after 
being adjusted to neutrality. This was the same preparation as that used by Rowlands \& Williams (1941) to cause superovulation in immature rats. The extract was re-assayed in immature rats and was found to have retained its potency (Tripp, 1970). All doses of AP70B were divided equally over a period of 5 days and, unless otherwise stated, the animals were killed on the 6th day for histological evaluation of the treatment. Details of dosage are given in the results section.

\section{RESULTS}

\section{The ovaries}

The ovaries of all the species of elephant-shrew examined were completely enclosed within a capsule lined by columnar epithelium. In E. myurus, this capsule has been identified as part of the infundibulum tubae (Van der Horst, 1942).

An E. myurus (EM 28) which died within $24 \mathrm{hr}$ of parturition showed preovulatory changes in many of the larger follicles (diameter 300 to $350 \mu \mathrm{m}$ ). The membrana granulosa was showing early signs of luteinization and was so expanded as almost to obliterate the antrum (Pl. 1, Fig. 1), but the theca interna did not show the signs of hypertrophy observed before ovulation by Van der Horst \& Gillman (1940b).

A specimen of E. myurus (EM 73) which died 4 days post partum had just ovulated and the ova were in the cranial end of the Fallopian tube. The freshly formed CL of this specimen were everted out of the surface of the ovary, being attached by only a narrow stalk. Specimens of $E$. rozeti, E. intufi and $P$. tetradactylus that had died, or had been killed shortly after ovulation also showed eversion of the CL (P1. 1, Figs. 2 to 4). An E. myurus (EM 26) that died 11 days post partum showed signs of having had an infertile ovulation and the CL were spherical bodies lying within the ovary.

It was observed that the zona pellucida was distorted or destroyed in those specimens fixed in Bouin's fluid (Pl. 1, Fig. 1), but remained intact until after ovulation in those specimens fixed in $5 \%$ formol-saline. In a specimen of $E$. rozeti (ERz 11), an intact zona was present on a four-cell stage embryo (Pl. 2, Fig. 5).

Sizes of CL in specimens from early pregnancy are recorded in Table 1 for all the species studied. For those species for which specimens at a suitable stage were lacking, a figure was estimated from specimens in later stages in pregnancy. It was noted that the sizes of CL tended to be related inversely to the mean CL. counts of the species studied.

\section{Ovulation rates}

In Van der Horst's histological material, the numbers of cL were counted as an estimate of the ovulation rate of $E$. myurus. Since only the left ovary of the majority of the specimens had been sectioned, the cL were first counted in a sample of ten specimens for which both ovaries had been sectioned. The mean number $(50.4)$ in the right ovary was not significantly different $(P>0.4)$ from 
that $(52.6)$ of the left, by the $t$ test. The cr counts of the left ovaries of the remaining specimens were then taken to represent one-half of their total ovulation rates.

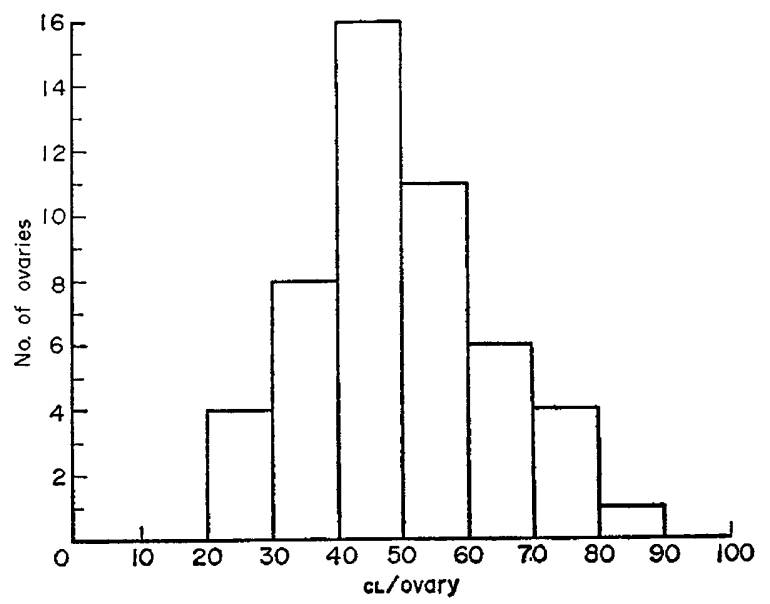

TEXT-FIG. 1. Frequency distribution of numbers of cL per ovary in a sample of fifty pregnant $E$. myurus.

The mean number of CL (49.2) in the left ovaries of ten specimens with embryos at the blastocyst stage was not significantly different $(P>0.8)$ from that $(48 \cdot 1)$ of another ten specimens in late pregnancy (embryos with crownrump lengths 27 to $35 \mathrm{~mm}$ ). This confirmed that the large numbers of cL were formed by ovulation and were not added to during pregnancy. Corpora lutea counts from the ovaries of fifty pregnant $E$. myurus were then pooled and the mean number calculated to be 49.0 per ovary (S.D. $=14 \cdot 2$ ). The range of values in this sample was from twenty-five to eighty-nine cL per ovary. The frequency distribution, tested by the method of Chambers (1952) was found to be normal (see Text-fig. 1).

The mean cL counts of all the other species studied are recorded in Table 1 and are represented in Text-fig. 2. For each of the species, E. intufi, E. rozeti, E. rufescens, $E$. brachyrhynchus and $P$. tetradactylus, more than six complete specimens were available. No significant differences were found between the numbers of $\mathrm{CL}$ in the right and left ovaries of these specimens. Samples of all the remaining species were too small to allow firm conclusions to be drawn about their mean

\section{EXPLANATION OF PLATE 1}

Fic. 1. E. myurus (EM 28). Section through a preovulatory follicle in the ovary of a specimen that died on the 1st day post partum. The membrana granulosa has expanded and is showing early signs of luteinization. The zona pellucida is vacuolated as a result of fixation in Bouin's fluid. $\times 188$.

FIG. 2. P. tetradactylus (PT 3). Section of ovary of a specimen that died shortly after ovulation, showing an everted CL. $\times 43$.

Fig. 3. E. rozeti (ERz 11). Section of part of ovary of a specimen that was killed about 4 days after ovulation, showing an everted cL. $\times 77$.

FIG. 4. E. intufi (EI 11). Section of part of ovary of a specimen that died shortly after ovulation, showing an everted CL. $\times 62$. 
PI.NTL:
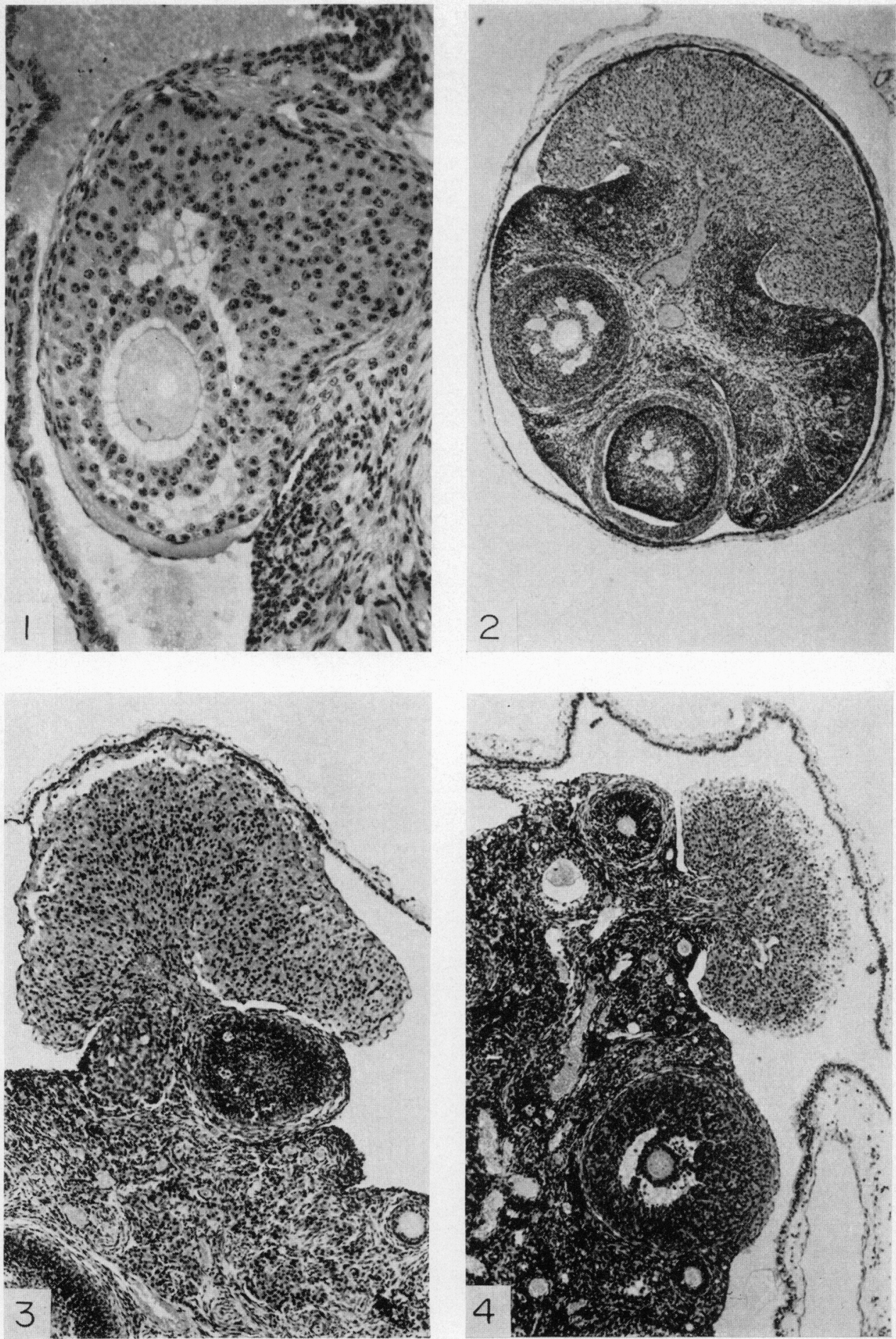

Fituins p. 1.52 
PLATE
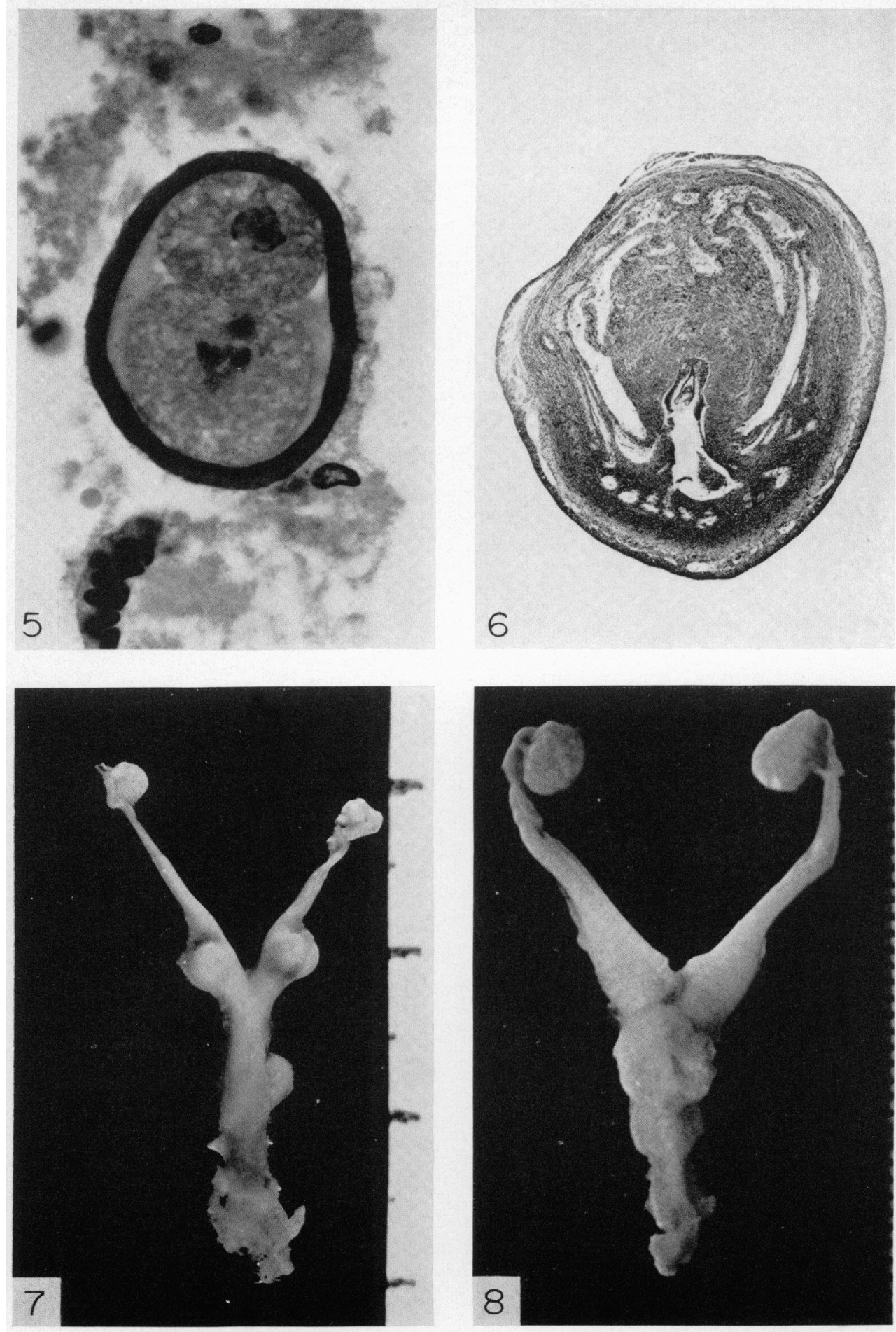

(Facing p. 153) 
TABLE 1

NUMBERS AND SIZES OF GORPORA LUTEA IN ELEVEN SPECIES OF ELEPHANT-SHREW

\begin{tabular}{|c|c|c|c|c|c|}
\hline \multirow{2}{*}{ Species } & \multirow{2}{*}{$\begin{array}{c}\text { No. of } \\
\text { ovaries in } \\
\text { which } C L \\
\text { were counted }\end{array}$} & \multicolumn{2}{|c|}{ No. of CLlovary } & \multirow{2}{*}{$S . D$. } & \multirow{2}{*}{$\begin{array}{c}\text { Mean diameter } \\
\text { of } C L \text { in } \\
\text { early } \\
\text { pregnancy }(\mu m)\end{array}$} \\
\hline & & Mean & Range & & \\
\hline $\begin{array}{l}R . \text { petersi } \\
P . \text { tetradactylus } \\
E . \text { fuscipes } \\
E . \text { rupestris } \\
E . \text { rufescens } \\
E . \text { rozeti } \\
\text { E. intufi } \\
E . \text { brachyrhynchus } \\
M . \text { proboscideus } \\
E . \text { edwardi } \\
\text { E. myurus }\end{array}$ & $\begin{array}{r}2 \\
18 \\
2 \\
2 \\
13 \\
23 \\
29 \\
16 \\
2 \\
3 \\
50\end{array}$ & $\begin{array}{r}1 \cdot 0 \\
0.6 \\
0.5 \\
0.5 \\
0.7 \\
1 \cdot 2 \\
2 \cdot 5 \\
8 \cdot 5 \\
21 \cdot 0 \\
44 \cdot 0 \\
49 \cdot 0\end{array}$ & $\begin{array}{l}0 \text { to } 2 \\
0 \text { to } 2 \\
0 \text { to } 1 \\
0 \text { to } 1 \\
0 \text { to } 2 \\
0 \text { to } 3 \\
0 \text { to } 8 \\
0 \text { to } 23 \\
31 \text { to } 55 \\
25 \text { to } 89\end{array}$ & $\begin{array}{l}0.69 \\
\\
0 \cdot 60 \\
0.85 \\
2 \cdot 50 \\
6 \cdot 60 \\
\\
14 \cdot 20\end{array}$ & $\begin{array}{l}975 \\
1150^{*} \\
800 \\
750^{*} \\
750 \\
730 \\
585 \\
550^{*} \\
425 \\
275 \\
325 \dagger\end{array}$ \\
\hline
\end{tabular}

* Estimates based upon specimens at later stages of pregnancy.

$\uparrow$ From Van der Horst \& Gillman (1946).

ovulation rates. Only three species of elephant-shrew $(E$. revoili, $R$. chrysopygus and $R$. cimei) were not represented in this part of the study.

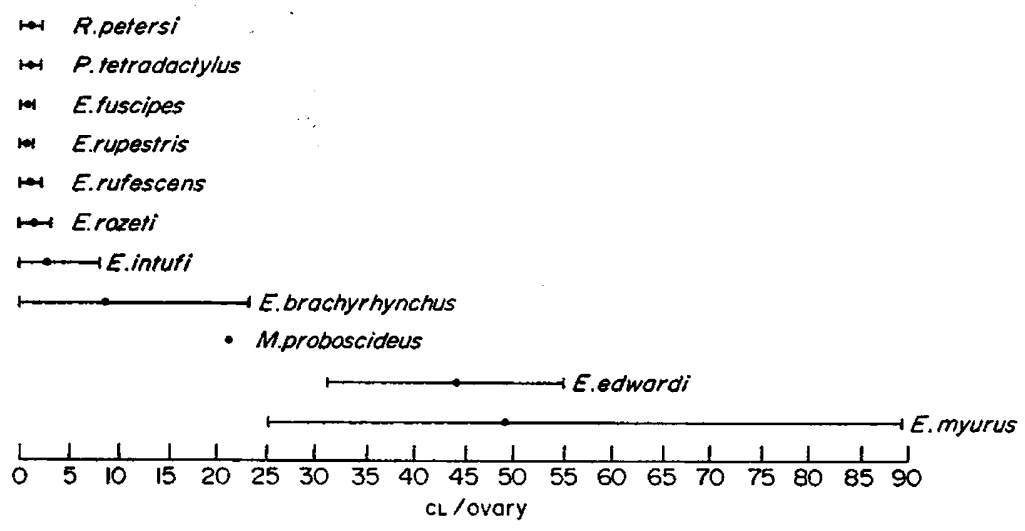

TEXT-FIG. 2. Mean and range of ovulation rates in eleven species of elephant-shrew.

\section{Experimentally induced ovulation}

In a series of pilot experiments, individual $E$. myurus were injected with PMSG in doses ranging from 15 to 300 i.u. divided equally into three daily doses,

\section{EXPLANATION OF PLATE 2}

Fic. 5. E. rozeti (ERz 11). Section of a four-cell stage embryo in the uterus of a specimen that was killed about 4 days after a fertile ovulation. The specimen was fixed in $5 \%$ formol-saline and the zona pellucida is intact. $\times 750$.

Frg. 6. E. rozeti (ERz 15). Cross-section of uterus (pictured in Pl. 2, Fig. 7) showing an embryo in an early stage of implantation surrounded by decidua. $\times 28$.

FIG. 7. E. rozeti (ERz 15). Dorsal view of female reproductive tract in early pregnancy. $\times 2 \cdot 4$.

Fig. 8. E. myurus (EM 45). Ventral view of non-pregnant female reproductive tract. $\times 2.4$. 
followed by a single dose of HCG ( 5 or 10 i.u.) on the 4 th day and the animals were killed on the 6th day for histological evaluation of treatment. Only one fresh cL was found in one of the six animals so treated. Two more animals were injected with 700 i.u. of PMSG divided over a period of 7 days; one of these received a further dose of 100 i.u. of HCG and both animals were killed 2 days after the last injection. There were no signs of ovulation although antral follicles were present. In these and the following experiments, the exact reproductive states of the animals at the start of the experiments was unknown, but from their body weights they were not obviously pregnant.

All further attempts to induce ovulation involved the use of the gelding pituitary extract (AP70B). The first E. myurus (EM 46) was given a dose of 50 $\mathrm{mg}$ and eighteen ovulations resulted, but the presence of many luteinized follicles indicated that stimulation had been excessive. The next animal (EM 24) was given $5 \mathrm{mg}$ without effect. The third animal (EM 15) was given $15 \mathrm{mg}$ and ninety fresh CL were counted in the ovaries. A further seven animals were treated with $15 \mathrm{mg}$ of $\mathrm{AP} 70 \mathrm{~B}$ and were killed at intervals up to 17 days after treatment. The intention of the delay was to study the rate of regression of the GL. Four of the eight animals treated with $15 \mathrm{mg}$ of AP70B were judged to have ovulated as a result of treatment, producing an average of forty-two ovulations per animal.

Two E. intufi were treated with $15 \mathrm{mg}$ of AP70B and both were found to have large cL, apparently from a previous ovulation. There were no antral follicles and no ovulation was induced by the treatment. Of four E. rozeti which were treated with $15 \mathrm{mg}$ of $\mathrm{AP} 70 \mathrm{~B}$, one animal had no $\mathrm{CL}$ and the other three were judged to have ovulated before the experiment.

\section{The reproductive tract}

It was observed that the uterine horns of $E$. myurus joined to form a median uterus which was slightly glandular and lined by a columnar epithelium. This median uterus opened into a shallow urinogenital sinus. A cervix and true vagina were absent. No regular variations in cell type were noticed in the smears taken from this region of the tract and the cornified cells typical of oestrus in most other mammals were seen only sporadically.

Intact $E$. myurus were used to observe the effect of exogenous oestrogen on the smear obtained from the median uterus. Three applications of $0.1 \mu \mathrm{g}$ of $17 \beta$-oestradiol were made into the lumen for 2 days. This treatment, which produced a cornified vaginal smear in intact mice, was ineffective in $E$. myurus and a ten-fold increase in dosage caused only an insignificant amount of cornification.

The reproductive tracts of the six other species of Elephantulus (those listed in Table 2), $M$. proboscideus and $P$. tetradactylus all presented essentially the same anatomical appearance as that encountered in E. myurus (Pl. 2, Fig. 8). But no suitably preserved, complete reproductive tracts of $E$. fuscipes and $M$. proboscideus were available for histological examination of the median uterus. The reproductive tract of $P$. tetradactylus was larger than those of the Elephantulus species, in keeping with the greater body size of this species. The largest species of elephant-shrew belong to the genus Rhynchocyon. In the only preserved tract of 
$R$. petersi that was available, the uterine horns were short, stout bodies, as described for $R$. cirnei (Peters, 1852). This is in contrast to the slender, tapering uterine horns of all the other species studied. The size of the uterine horns $(5 \times 10 \mathrm{~mm}$ at their widest point) was obviously accentuated by the early pregnancy in each horn of this specimen.

\section{Implantation}

The author's material of $E$. myurus did not allow independent assessment of uterine changes in early pregnancy, but specimens of all the other species studied (except $M$. proboscideus) were examined during this period. Implantation swellings were found only at the caudal end of the uterine horns (Pl. 2, Fig. 7). Implantation was mesometrial and accompanied by an extensive decidual reaction which became surrounded by enormously expanded uterine glands (Pl. 2, Fig. 6). The embryo counts for all stages of pregnancy are presented in Table 2. With the exception of E. rozeti, no species was found to carry more than

TABLE 2

\begin{tabular}{|c|c|c|c|c|c|}
\hline \multicolumn{6}{|c|}{$\begin{array}{l}\text { COUNTS IN NINE SPEGIES } \\
\text { ELEPHANT-SHREW }\end{array}$} \\
\hline Species & & 1 & $\begin{array}{r}\text { Treque } \\
2 m b\end{array}$ & $\begin{array}{c}\text { ncy of total } \\
\text { ryo count } \\
3\end{array}$ & 4 \\
\hline $\begin{array}{l}\text { R. petersi } \\
P . \text { tetradactylus } \\
\text { E. fuscipes } \\
\text { E. rufescens } \\
\text { E. rozeti } \\
\text { E. intufi } \\
\text { E. brachyrhynchus } \\
\text { E. edwardi } \\
\text { E. myurus }\end{array}$ & & $\begin{array}{l}6 \\
1 \\
4 \\
1 \\
4 \\
1\end{array}$ & $\begin{array}{r}1 \\
\\
3 \\
21 \\
2 \\
4 \\
1 \\
2\end{array}$ & 12 & 2 \\
\hline
\end{tabular}

two implanted embryos; this is in accordance with previous observations (Shortridge, 1934; de Lange, 1949; Brown, 1964). Litters of up to four advanced foetuses ( $25 \mathrm{~mm}$ crown-rump length) were found in $E$. rozeti, but there were never more than two embryos in a single uterine horn. In the only specimen $(\mathrm{ERz} 31)$ with two early embryos in the same horn, the two blastocysts were spaced $3.3 \mathrm{~mm}$ apart, as measured through serial sections. Some of the embryo counts for $E$. rozeti given in Table 2 were taken from the unpublished catalogue of the Hubrecht Collection and were not based upon the author's own observations.

\section{DISCUSSION}

The present study confirms the observation of Van der Horst (1942) that a true vagina is absent in $E$. myurus. Since a similar condition was found in six other species examined, it is likely that it is characteristic of the entire family. A similar condition has been reported in a number of other mammals, but the 
anatomical interpretations tend to be controversial. The armadillos are without a cervix and vagina (Altmann, 1924; Newfang, 1947), but the status of this portion of the reproductive tract is more controversial in the hippopotamus (Chapman, 1881; Laws \& Clough, 1966), sloth, anteater (Wislocki, 1928; Becher, 1930) and the rabbit (Langenbacher, 1882; Baxter, 1933). Local administration of oestrogens and the examination of smears confirmed that the median uterus of elephant-shrews is physiologically unlike the typical mammalian vagina. The inability to detect oestrus in elephant-shrews by the vaginal smear technique has proved to be a serious handicap to the laboratory study of these animals.

The occurrence of ovulation in E. myurus before the 4th day post partum confirmed the observation of Van der Horst (1951). The eversion of freshly formed cL seen in this species confirmed the report of Van der Horst \& Gillman (1940b). Similarly everted cL were observed for the first time in the three other species for which there was suitable material. Since its occurrence was not related to the mean ovulation rates of the species concerned, it may be characteristic of the family Macroscelididae. This feature has also been reported as a regular occurrence in two species of tenrec, Hemicentetes semispinosus and Setifer (Ericulus) setosus (Strauss, 1939) and in the shrew, Suncus murinus (Dryden, 1969).

The observed persistence of the zona pellucida after ovulation in those specimens fixed in formol-saline suggests that the claim that it was shed at ovulation (Van der Horst \& Gillman, 1940b) was based upon an artifact due to fixation in Bouin's fluid.

The author's observations confirm those of Van der Horst (1944) in so far as marked differences were found between the mean ovulation rates of some species of elephant-shrew. However, the present study, based upon larger samples of more species than the study of Van der Horst, conflicts with the details of his conclusions. There was no clear division of the Macroscelididae into a group of polyovulating species and a group of oligo-ovulating species, in contrast to the conclusion of Van der Horst (1944). Although about one-half of the species studied so far $(R$. petersi, $P$. tetradactylus, $E$. rozeti, E. rufescens, E. fuscipes and $E$. rupestris) can be assigned to an oligo-ovulating group, the remaining species show a complete range of ovulation rates, $E$. myurus having the highest rate. $E$. intufi and $E$. brachyrhynchus might be considered intermediate forms in this respect. These variations in ovulation rate appear to be unrelated to any environmental factor in so far as the distributions of many polyovulating and oligo-ovulating species overlap (Corbet \& Hanks, 1968).

The author's calculation of the mean ovulation rate for $E$. myurus as 49.0 per ovary is less than that of 60 quoted by Van der Horst \& Gillman (1941); their figure, however, was based upon a sample of only five specimens. Van der Horst \& Gillman (1940a) suggested two physiological explanations for the exceptionally high ovulation rate of $E$. myurus: either (i) unusually potent gonadotrophins are released from the pituitary gland, or (ii) the ovary is unusually responsive to normal levels of gonadotrophin. A dose of $15 \mathrm{mg}$ of gelding pituitary extract (AP70B) was found to induce a mean ovulation rate of 42 per animal. Although this is only $40 \%$ of the normal ovulation rate of $E$. myurus, it was concluded that, of the doses used in the study, $15 \mathrm{mg}$ was the 
optimal one. The administration of this same dose to a few specimens of $E$. intufi and $E$. rozeti did not result in ovulation and so it was not possible to compare their ovarian sensitivity with that of $E$. myurus. On the basis of these experiments, it was not possible to decide between the two explanations proposed by Van der Horst \& Gillman.

The only instance of polyovulation comparable with that occurring in some elephant-shrews is that recently discovered in the plains viscacha, Lagostomus maximus by Weir (1971). Preliminary observations have shown that one animal shed more than 800 ova at oestrus. It is noted in all these polyovulating species that the range of individual variation in the numbers of ova shed increases in proportion to the mean ovulation rate of the species. This may indicate that any selective pressures determining their ovulation rates are weak. It has been suggested that there is an advantage in producing large numbers of ova in that it allows selection of the most viable embryos (Cohen, 1969). Although it would be impossible for all the eggs produced by polyovulators to implant and come to term, it is noteworthy that this phenomenon is associated with particularly small litter sizes at birth. In those elephant-shrews that polyovulate, the final litter size appears to be determined entirely by the restricted implantation sites but in L. maximus, seven or eight embryos were reported by Weir (1971) to become implanted. The reduction of the litter size at birth to two young is the result of postimplantation losses. However, in the oligo-ovulating species of elephant-shrew, the mean ovulation rate is less than two and is very nearly equal to the mean litter-size. In these cases, it is not necessary to invoke a restriction upon implantation to determine the litter size. But the observation that the position and histological appearance of the implantation swelling were the same as in the polyovulating species suggests that there are restricted (or, at least, preferential) implantation sites in these species also. E. rozeti is exceptional amongst elephant-shrews in that implantation is not restricted to two sites. However, on the present evidence it is not possible to say whether implantation is restricted to four sites, or is completely unrestricted in this species.

Restriction of implantation to one uterine horn or a particular region of the uterus has been reported in certain bats that normally ovulate only one ovum at a time. For example, in the Indian fruit bat, Pteropus giganteus, implantation occurs only at the cranial end of the uterine horn (Marshall, 1953). There are four species of insectivorous bat in which implantation has only been reported in the right uterine horn. However, it is possible that greater numbers of these animals need to be examined before the possibility of implantation in the left horn can be excluded. The species concerned are Miniopterus natalensis (Asdell, 1964), Myotis griscescens, Myotis sodalis (Prahlad \& Conaway, 1962) and Vespertilio murina (Pearson, 1949).

High ovulation rates accompanied by large litters have been reported in the tenrecs, Centetes ecaudatus and Hemicentetes semispinosus (Kaudern, 1914; Rand, 1935; Bluntschli, 1937, 1938). Although these data have not been treated statistically, it is unlikely that the ovulation rates are of the same order of magnitude as in E. myurus. Similarly, large numbers of embryos have been reported in the marsupials, Dasyurus viverrinus (Hill, 1910) and Didelphis virginiana (Hartman, 1929), but the litter sizes of these animals during pouch-life are restricted by 
the number of functional nipples available. These may be considered analogous to the restricted implantation sites of the elephant-shrews. High ovulation rates and large litters are well documented for the domestic pig, but this situation has been exaggerated by selective breeding (Perry, 1954).

\section{ACKNOWLEDGMENTS}

This research was supported by a Ford Foundation grant administered by the Zoological Society of London. The author is grateful to the following for the donation and loan of preserved material: The British Museum (Natural History); The Hubrecht Laboratory, Utrecht; Dr J. Clevedon Brown of the University of Cardiff; Professor B. I. Balinsky of the University of the Witwatersrand, Johannesburg; $\mathrm{Dr}$ T. D. Glover of the University of Liverpool.

Gratitude is due to Dr D. H. S. Davis and other members of the staff of the Medical Ecology Unit, South African Institute for Medical Research, Johannesburg, for supplying some live animals and assisting in the capture and transport of others.

The author is especially grateful to Dr I. W. Rowlands of the Zoological Society of London for his supervision of this study and for his advice in the preparation of this paper. The substance of this paper was presented as part of a $\mathrm{Ph} . \mathrm{D}$. thesis at the University of London, 1970.

\section{REFERENCES}

Altmann, F. (1924) Beiträge zur Anatomie des weiblichen Genitales der Dasypodiden. Z. Anat. EntwGesch. 72, 390.

Asdelz, S. A. (1964) Patterms of mammalian repraduction, 2nd edn. Constable, London.

BaXter, J. S. (1933) The development of the vagina of the rabbit. F. Anat. 67, 555.

Becher, H. (1930) Über Drüsen in kavernösen Räumen, endoepitheliale Drüsen und die Verbreitung des Zylinderepithels im weiblichen Genitalkanal von Tamandua tetradactyla L. (Myrmecophaga). Z. mikrosk.-anat. Forsch. 20, 253.

Bluntschly, H. (1937) Die Frühentwicklung eines Centetinen (Hemicentetes semispinosus Cuv.). Revue suisse Zool. 44, 271.

BudnTschu, H. (1938) Le développement primaire et l'implantation chez un centetiné (Hemicentetes). C. r. Ass. Anat. 33, 39.

Brown, J. C. (1964) Observations on the elephant shrews (Macroscelididae) of equatorial Africa. Proc. zool. Soc. Lond. 143, 103.

ButLer, P. M. (1956) The skull of Ictops and the classification of the insectivora. Proc. zool. Soc. Lond. $126,453$.

Chambers, E. G. (1952) Statistical calculation for beginners, 2nd edn. Cambridge University Press.

Chapman, H. C. (1881) Observations upon the hippopotamus. Proc. Acad. nat. Sci. Philad. 126.

CoHen, J. (1969) Is sexual reproduction wasteful? New Scient. 44, 282.

Corbet, G. B. \& Hanks, J. (1968) A revision of the elephant shrews, family Macroscelididae. Bull. Br. Mus. nat. Hist. 16, 47.

DE LANGE, D. (1949) Communications on the attachment and early development of Macroscelides (Elephantulus) rozeti Duv., the North-African jumping shrew, Bijdr. Dierk. 28, 255.

Dryden, G. L. (1969) Reproduction in Suncus murinus. F. Reprod. Fert., Suppl. 6, 377.

Hartman, C. G. (1929) Some excessively large litters of eggs liberated at a single ovulation in mammals. 7. Mammal. 10, 197.

HrLL, J. P. (1910) The early development of the marsupialia, with special reference to the native cat (Dasyurus viverrinus). $Q . \mathcal{F l}$ microsc. Sci. 56, 1.

KaUdern, W. (1914) Einige Beobachtungen über die Zeit der Fortpflanzug der madagassischen Säugetiere. Ark. Zool. 9, 1.

LANGEnBacher, L. (1882) Beitrag zur Kenntniss der Wolff'schen und Müller'schen Gänge bei Säugern. Arch. mikrosk. Anat. EntwMech. 20, 92. 
Laws, R. M. \& Glough, G. (1966) Observations on the reproduction in the hippopotamus, Hippopotamus amphibius Linn. Symp. zool. Soc. Lond. 15, 117.

Marshall, A. J. (1953) The unilateral endometrial reaction in the giant fruit-bat (Pteropus giganteus Brünnich). F. Endocr. 9, 42.

Newfang, D. (1947) Sex differentiation in the nine-banded armadillo, Dasypus novemcinctus. $\mathcal{F}$. Morph. 81, 283.

Patterson, B. (1965) The fossil elephant shrews (family Macroscelididae). Bull. Mus. comp. Zool. Harv. 133, 295.

Pearson, O. P. (1949) Reproduction of a South American rodent, the mountain viscacha. Am. F. Anat. $84,143$.

Perry, J. S. (1954) Fecundity and embryonic mortality in pigs. F. Embryol. exp. Morph. 2, 308.

Peters, W. C. H. (1852) Naturwissenschaftliche Reise nach Mossambique 1. Zoologie, Säugethiere. Georg Reimer, Berlin.

Prahlad, K. V. \& Conaway, G. N. (1962) Alkaline phosphatase activity of bat uteri in relation to implantation. Proc. natn. Inst. Sci. India, 28, 89.

Rand, A. L. (1935) On the habits of some Madagascar mammals. F. Mammal. 16, 89.

Rowland, I. W. \& Williams, P. C. (1941) Comparative activity of the gonadotrophin in horse pituitary glands and in pregnant mares' serum. F. Endocr. 2, 380.

Shortringe, G. C. (1934) Mammals of south west Africa, vol. 1, p. 16. Heinemann, London.

Simpson, G. G. (1945) The principles of classification and a classification of mammals. Bull. Am. Mus. nat. Hist. 85, 1.

Strauss, F. (1939) Die Bildung des Corpus luteum bei Centetiden. Biomorphosis, 1, 489.

TRIPP, H. R. H. (1970) Reproduction in the Macroscelididae with special reference to ovulation. Ph.D. thesis, University of London.

VAN DER HORST, C. J. (1942) Some observations of the structure of the genital tract of Elephantulus. 7. Morph. 70, 403.

VAN DER HoRst, G. J. (1944) Remarks on the systematics of Elephantulus. F. Mammal. 25, 77.

VAN DER Horst, G. J. (1951) The post-partum involution of the uterus of Elephantulus. Acta zool., Stockh. 32, 11.

VAN DER Horst, C. J. \& Gillman, J. (1940a) Extreme polyovulation and the factors determining the survival of a single embryo in each uterine horn in Elephantulus. S. Afr. F. Sci. 37, 249.

VAN Der Horst, C. J. \& Gillman, J. (1940b) Ovulation and corpus luteum formation in Elephantulus. S. Afr. F. med. Sci. $5,73$.

VAN DER HORST, C. J. \& GILlman, J. (1941) The number of eggs and surviving embryos in Elephantulus. Anat. Rec. 80, 443.

Van der Horst, C. J. \& Gillman, J. (1942) Preimplantation phenomena in the uterus of Elephantulus. S. Afr. F. med. Sci. 7, 47.

VAN DER HORST, C. J. \& Gillman, J. (1946) The corpus luteum of Elephantulus during pregnancy, its form and function. S. Afr. F. med. Sci. 11, Biol. Suppl. 87.

WerR, B. J. (1971) The reproductive organs of the female plains viscacha, Lagostomus maximus. $\mathcal{F}$. Reprod. Fert. 25, 365.

Wislocki, G. B. (1928) Observations on the gross and microscopic anatomy of the sloths (Bradypus griseus griseus Gray and Choleopus hofmanni Peters). F. Morph. 46, 317. 